\title{
The effect of Think Pair Share (TPS) learning model with problem solving approach to students' mathematical communication in MA DA Jarowaru
}

\author{
Samsuriadi $^{1^{*}}$ and Muhammad Ali Imron ${ }^{1}$ \\ Universitas Nahdlatul Wathan Mataram, Mataram, Indonesia \\ ${ }^{*}$ Corresponding author: samsuriadirambo@gmail.com | Phone Number: +6281805548352
}

\section{ARTICLE HISTORY}

Received : 3 January 2019

Revised : 20 February 2018

Accepted : 15 March 2018

\section{KEYWORDS}

Think Pair Share;

Problem Solving Approach;

Student's Math;

Communication;

\begin{abstract}
The purpose of this study was to determine the effect of Think Pair Share (TPS) learning models with problem solving approaches. The approach used in this research is a qualitative approach with the type of experimental research "The effect of Think Pair Share (TPS) learning model with problem solving approach to students' mathematical communication in MA DA Jerowaru. Model Pair Pair Share (TPS), as the name "Thinking" learning begins with the teacher asking questions or issues related to the lesson for students to think about, "pairing", at this stage the teacher asks students to pair up pairs. Give the couple a chance to discuss. It is hoped that this discussion will be able to deepen the meaning of the answers they have thought through intersubjectives with their partners. The results of intersubjective discussions in each pair of results are discussed with the whole class pair. This stage is known as "sharing" in this activity. It is expected that question and answer will occur which encourages the integrative management of knowledge. Added to this is the emphasis on problem solving, namely the Problem Solving approach. Problem Solving is an approach that teaches students how to solve a problem. Meanwhile, according to Heriawan (in Istiqoma and Rusdi, 2012: 92). Problem Solving is a way of presenting learning material by making problems as a starting point for discussion to be analyzed in an effort to find solutions or answers by students.
\end{abstract}

This is an open access article under the CC-BY-SA license.

\section{INTRODUCTION}

Education is an important activity and is necessary to improve human resources now and in the future, according to the Law of the Republic of Indonesia No. 20 of 2003 concerning the National Education System Chapter 1 Article 1 states education is a conscious and planned effort to create a learning atmosphere and learning process so that students actively develop their potential to have the spiritual strength of their religion, self-control, personality, intelligence, noble character, and the skills needed by himself, society, nation and state. The function of National Education is to develop capabilities and shape the character and dignity of a dignified nation in the context of educating the nation, aiming at developing students to become people of faith and devotion to God Almighty, noble, healthy, knowledgeable, capable, creative, independent, and citizens. democratic and responsible. So, are the steps or procedures taken to achieve goals.

According to Soedjadi (2000) several definitions of mathematics, namely: (a) mathematics is an exact and systematically organized branch of science, (b) mathematics is knowledge of numbers and calculations, (c) mathematics is knowledge of logical reasoning and dealing with numbers, (d) mathematics is knowledge of quantitative facts and problems about space and form, (e) mathematics is knowledge of logical structures, and (f) mathematics is knowledge of strict rules.

Budiningsih, (2005) The constructivist learning theory recognizes that students interpret information into their minds, only in the context of their own experiences and knowledge, on their needs, backgrounds and interests "This is consistent with what Hamalik expressed, (2002) that teaching is conveying knowledge to students or students in school, efforts to organize the environment so as to create conditions for learning for students, provide guidance to students. According to Nur, (2001) the main idea of constructivism learning is students actively building their own knowledge. Hujono (1998:7) a learning environment that (1) provides a learning experience that links new knowledge to students' existing knowledge so learning is a process of forming knowledge, (2) provides a variety of alternative learning experiences, (3) integrates learning with realistic situations and relevant to involving concrete experiences (4) integrating learning that enables interaction and cooperation between students, (5) utilizing various media to make learning more interesting, and (6) involving students, emotionally and socially so that mathematics is more interesting and students want to learn. 
The desire to improve the condition of education continues to be developed in line with the new paradigm of education that emphasizes more on students as humans who have the potential to learn and develop. Students must be active in the search and development of knowledge. The truth of science is not limited to what is conveyed by the teacher. The teacher must change his role, no longer as the highest authority in scientific knowledge, but as a facilitator who guides students towards the construction of knowledge by themselves.

Based on an interview with one of the MA teachers namely MA mathematics teacher Darul Aitam Jerowaru, this is apparent when the teacher gives a problem, students only listen and accept things that are conveyed by the teacher, students do not want to ask questions and prefer silence if they do not understand the lesson explained by the teacher, some students do not work on problems, practice questions provided by the teacher and prefer to play around, some students do not take notes when learning mathematics takes place, and lack of reciprocity between students and students, students and teachers, learning models used there is still no variation. Resulting in students feeling lazy, bored, and not active in learning, the low level of mathematical communication of students is also influenced by the learning model used by the teacher, which results in students only being able to listen and pay attention to the teacher delivering the subject matter. Teaching and learning like this will obviously hinder the learning objectives listed in the competency standards and basic competencies. This is of course contrary to constructivist ideology which defines learning as the active process of students constructing the meaning of text, dialogue, physical experience, and others.

Based on the description of the problem above, the researcher offered one of the learning models, namely Think Pair Share (TPS) learning model with problem solving approach. Model Pair Pair Share (TPS), as the name "Thinking" this learning begins with the teacher asking questions or issues related to the lesson for students to think about, "pairing", at this stage the teacher asks students to pair up pairs. Give the pairs the opportunity to discuss. Hopefully this discussion can deepen the meaning of the answers they have thought through intersubjectives with their partners. The results of intersubjective discussions in each pair of the results are discussed with pairs throughout the class. This stage is known as "sharing" in this activity is expected to occur question and answer that encourages the integration of knowledge knowledge. In addition, the emphasis on problem solving is the Problem Solving approach.

Problem Solving is an approach that teaches students how to solve a problem. Meanwhile, according to Heriawan (in Istiqoma and Rusdi, 2012: 92). Problem Solving is a way of presenting learning material by making problems as a starting point for discussion to be analyzed in an effort to find solutions or answers by students.

The steps of the problem solving method. According to Djamarah (in Istiqoma and Rusdi, 2013: 92), among others: a). There are clear problems to be solved, b). Looking for data or information that can be used to solve the problem, c). Establish a temporary answer to the problem. This alleged answer is of course based on the data that has been obtained, in the second step above, d). Test the correctness of the temporary answer. In this step students must try to solve the problem so that it is really suitable, e). Draw conclusions

By using Think Pair Share (TPS) learning models and Problem Solving approaches teachers are able to encourage students to reflect on their work and clarify ideas for them. When students are involved communicatively in working on mathematical problems, they are asked to think about their ideas, or talk and listen to other students, in sharing ideas, strategies and solutions. If using a model that is appropriate to the circumstances of the students, the learning activities that are pursued will increase opportunities for teachers to obtain good results in the learning process. Therefore, the role and function of the teacher is very important in the learning process, because the situation faced by the teacher in carrying out teaching has a great influence on the learning activities themselves. Thus, teachers are more sensitive to various situations encountered, so they can adjust.

Based on the description above, researchers are interested in conducting research with the title: "The influence of Think Pair Share (TPS) learning models with a problem solving approach to students' mathematical communication .

Based on the background above, the problem formulation in this study. Is there an influence of Think Pair Share (TPS) learning model with problem solving approach to students' mathematical communication?

The purpose of this study is to determine whether there is an influence of Think Pair Share (TPS) learning model with the approach of problem solving to mathematical communication.

This research is focused on student communication. The learning in this study, uses the Think Pair Share (TPS) learning model with a problem solving approach to students' mathematical communication.

\section{DATA TYPES AND SOURCES}

1. Types and sources of data 1) Types of Data used in this study are quantitative data.

2. Data Sources used in this study are primary data and secondary data. Primary data consisting of student learning outcomes. While secondary data is data that is not directly obtained from the first source such as a written document.

Data collected in this study include: The results of the validation of the Learning Implementation Plan (RPP), Student Worksheets (LKS), observation sheets of teacher and student activities, test sheets. The results of observations of teacher activities and student activities in learning. Pre-test and post-test results

Research data are collected naturally from the source. The data sources in this study were the validator, the teacher, and all MA DA Jerowaru students in the odd semester of the $20117 / 2018$ school year who participated in cube and beam learning.

Data collection procedures performed in this study are as follows: The validation data is obtained from expert validation of the learning instruments that have been prepared by researchers. The selected experts are experts who are competent in their fields. Observations were made to observe activities in the class during the learning process. Observed activities include the activities of researchers as instructors and student activities during the learning process. Observations were made by mathematics teachers and peers. Data of test results to be performed. 


\section{METHOD}

Data collection techniques used in research by researchers are (1) Documentation in carrying out this documentation method the researcher investigates the notes, books, information boards and so on in the research location. (2) Tests, tests are questions or exercises as well as other tools used to measure the knowledge and abilities possessed by individuals or groups. The material used is matrix material, which is in the form of description questions, as many as 5 items.

\section{RESULT AND DISCUSSION}

The data of this study indicate that the results of the field notes conducted by 2 observers during the learning process and the analysis of the data conducted by the students' work on the test, obtained the percentage of successful student activities as follows: Observations were made by observers during the study. Observation is directed at student and teacher activities during learning activities, where both observers fill out student observation sheets and teacher activity observation sheets based on their observations. Accumulatively, observers' observations of student activities on observations of student activities are categorized sufficiently by the percentage score $79.6 \%$ of this shows that the activities carried out by students are very good

Based on the initial purpose of the study, which is to determine the effect of constructivism-based inquiry models in mathematics learning on the communication of students of class XI MA Darul Aitam Jerowaru 2018/2019 Academic Year, the researchers conducted hypothesis testing by comparing communication of classroom learning experiments ie classes taught with models TPS with Problem solving approach with students who are taught using conventional methods.

The design used was Pretest-posttest only control design by giving pretest before being given treatment and posttest after being given treatment. Pretest was done with the aim to find out how much the readiness of students in conducting the learning process before being given treatment to each experimental and control group.

The average pretest results of the experimental group were 56.25 and the average control group was 40. In addition, the scores obtained by each group were also normally distributed, namely preetes in the experimental group. The data obtained from the posttest results obtained an average group. experiment 79,6 and control group 54, the scores of both groups were normally distributed ie in the control group Lhitung $>$ Ltable $(0.425)>(0.184) \mathrm{L}$ calculated experiments $<\mathrm{L}$ table $(0.468)<(0.184)$ and Posttest was given to each group with the aim is to evaluate the treatment that has been given to each group. Data obtained from the posttest results obtained an average of 79.6 experimental group and 54 control groups, both groups were normally distributed, namely in the control group Lhitung $>$ Ltable $(0.425)>(0.184)$ L calculated experiment $<$ L table $(0.468)<(0.184)$. Data obtained from the two groups are not much different and are classified as homogeneous because Fcount $<$ Ftable (3.97) <4.32). From the results obtained it appears that the communication results of students in the experimental class (XI IPS A) is better when compared to the learning achievement of students in the control class (X IPA B). This shows that teaching with the TPS model.

\section{CONCLUSION}

Based on the results of research and discussion, it can be concluded that the application of the TPS learning model with the problem solving approach to mathematics learning on average the results of the hypothesis test show that students' learning communication is more improved compared to the learning process that occurs in the control class. The average pretest results of the experimental group were 56.25 and the average control group was 40 . In addition, the scores obtained by each group were also normally distributed, namely preetes in the experimental group. The data obtained from the posttest results obtained an average group. experiment 79,6 and control group 54 .

\section{Suggestions}

As for the advice that researchers give, dalah as follows:

1. Students are expected to be more diligent and active in learning, especially in mathematics and more students in order to reproduce the exercises and do the practice questions.

2. Mathematics subject teachers are expected not to use monotonous/conventional methods, but they should introduce and familiarize students with varied models so that students feel unsaturated in the learning process so that mathematics becomes more fun and enjoyable.

3. Schools are expected to be able to meet the provision of a variety of learning media so that students not only understand conceptually, but understand the context and also subject teachers can more easily teach or express ideas in learning and the experience of students will be more developed and meaningful.

4. For other researchers

a. This research was conducted with very limited, so the results are also limited, therefore to other researchers in order to develop matters relating to the results of this study.

b. Further researchers are expected to use other methods that can improve the quality of student learning outcomes.

\section{REFERENCES}

Ariani, Noor, Dessy. (2017). Strategi Peningkatan Kemampuan Komunikasi Matematis Siswa. Jurnal Madrasah Ibtidakyah. Volume 3 No 1(halaman 96-107).

Budiningsih, C. Asri. 2005. Belajar dan Pembelajaran. Jakarta: Penerbit Rineka Cipta

Huda, Mifathaul. (2015). Cooprative Liearning Metode,Teknik,Struktur dan Model Terapan. Celeban Timur UHIII/ 548 Yogyajakarta 55167: Pustaka Pelajar.

Hasan, Muhammad Alwi. 2015. Pengaruh Model Pembelajaran Koopratife Tipe Think Pair Share ( TPS )Terhadap Hasil Belajar. Skiripsi . Anjani: Fakultas Univeritas Mataram.

Idel, Antoni. 2005. Pintar Matematika. JawaTimur: Gitamwdia Press.

Istiqoma, Fitria dan Rusdi, Amir. (2015).Pengaruh Penerapan Metode Problem Solving Padamata Pelajaran Matematika Materi Pecahan Terhadaphasil Belajar Siswa.Jurnal Pendidikan. Volume II (halaman 248-275). 
Mutazam, T Haris. 2018. "Peningkatan Kemampuan Komunikasi Matematis Siswa Melalui Metode Pembelajaran Thinking Aloud Pair Problem Solving (Tapps) Pada Siswa Mts (Skerpsi : Fakultas Tarbiyah Dan Keguruan Program Studi Pendidikan Matematika Universitas Islam Negeri Ar-Raniry,Banda Aceh,

Natalliasari, Ike. (2013). Penggunaan Model Pembelajaran Kooperatif Tipe Think Pair Share (TPS) untuk meningkatkan kemampuan penalaran dan pemecahan masalah matematis siswa. Skrispi. Tasikmalaya: Universitas Terbuka

Suprijono, Agus. (2016). Cooprative LiearningTeori dan Aplikasi PAIKEM. Celeban Timur UHIII/ 548 Yogyajakarta 55167: Pustaka Pelajar.

Sugiyono. (2010). Metode penelitian pendidikan pendekatan kuantitatif, kualiattif dan $R \& D$. Bandung: Alfabeta CV.

Sumiati, dan Asra. (2007). Metode Pembelajaran. Bumi Rancaekek Kencana- Bandung: CV Wacana Prima.

Surya, Edy, dan Rahayu, Riska. (2013). "Peningkatan Kemampuan Komunikasi dan Pemecahanmasalah Matematis Siswa Smp Ar-Rahman Percut Melalui Pembelajaran Kooperatif Tipe Student Teams Achievement Division (STAD)". Jurnal Pendidikan Matematika PARADIKMA. Volume VII Nomor I (Halaman 24-34).

Undang-Undang Revuplik Indonesia Nomor 20 Tahun 2000 tentang Sistem Pendidikan Nasional.2003. Jakarta: PT Emas Angka Jaya.

Wayudin. (2008). Pembelajaran dan Model-Model Pembelajaran (Edisi 3, 4dan 5). Jakarta: CV. Ipa Abog.

Wahyudin .2008.Peningkatan dan Pengayaan Matematika (Edisi 2).Jakarta: CV. Ipa Abog.

Soedjadi, R. (2000). Kiat Pendidikan Matematika di Indonesia. Konstatasi Keadaan Masa Kini Menuju Harapan Masa Depan. Jakarta: Depdiknas 